\title{
ХУДОЖНЯ РЕАЛІЗАЦІЯ КОНЦЕПТУ МАСКИ У РОМАНІ ЮРІЯ АНДРУХОВИЧА «ПЕРВЕРЗІЯ»
}

\author{
Аспірант кафедри теорії і методики украӥнської та світової літератури Підодвірна М. I., \\ Україна, м. Тернопіль, Тернопільський начіональний \\ педагогічний університет імені Володимира Гнатюка
}

DOI: https://doi.org/10.31435/rsglobal_wos/30062019/6555

\section{ARTICLE INFO}

Received: 10 April 2019

Accepted: 15 June 2019

Published: 30 June 2019

\section{ABSTRACT}

The article deals with the concept of mask, which is realized in the novel by Yuri Andrukhovich «Perversia». The mask of the author, the mask of the narrator and the mask of the character and the peculiarities of their functioning in the fiction text are explored.

\section{KEYWORDS}

mask, carnival, unreliable poster, mystification, Yuri Andrukhovych

Citation: Підодвірна М. I. (2019) Khudozhnia Realizatsiia Kontseptu Masky u Romani Yuriia Andrukhovycha «Perverziia». International Academy Journal Web of Scholar. 6(36). doi: 10.31435/rsglobal_wos/30062019/6555

Copyright: () 2019 Підодвірна М. I. This is an open-access article distributed under the terms of the Creative Commons Attribution License (CC BY). The use, distribution or reproduction in other forums is permitted, provided the original author(s) or licensor are credited and that the original publication in this journal is cited, in accordance with accepted academic practice. No use, distribution or reproduction is permitted which does not comply with these terms.

Вступ. Говорячи про постмодернізм в українській літературі, неможливо оминути ім'я Юрія Андруховича. Своїм першим романом «Рекреації» письменник засвідчив переформатування літературного канону: на зміну реалістичній прозі приходить карнавальна та епатажна. Свого апогею у вправлянні 3 постмодерним письмом автор досяг у романі «Перверзія». Головним персонажем та наратором твору $є$ Стах Перфецький, який постійно міняє імена та маски. Але, як зазначено в тексті: «Всього імен його було сорок, і жодне $з$ них не було справжнє, бо справжнього не знав ніхто, навіть він сам» [1, с. 318]. Кожна 3 масок визначає певний набір рис, котрі творять зовнішній вигляд та психологічний портрет персонажа. Часто маска перетворюється на певний стереотип, на схему, за якою діє герой. I в цьому випадку ми не можемо ідентифікувати справжню сутність, адже маємо справу з маскоюбез-обличчя. Читач за численними містифікаціями та низкою різноманітних масок-образів не може дійти остаточного висновку щодо постаті Стаса Перфецького та способу існування зображеного художнього світу. Вважаємо, що цей момент є частиною авторського задуму, а ключ до розуміння тексту полягає у реалізації феномену ненадійного розповідача. Мета: простежити художню реалізацію концепту маски романі «Перверзія» і звернути увагу на симптоми присутності ненадійного розповідача.

Виклад основного матеріалу. Третій роман Ю. Андруховича - засадничий у філософській парадигмі літературного об'єднання «Бу-Ба-Бу», яке сповідувало карнавальне необарокове світовідчуття з його особливостями і трансформаціями. Постмодернізм загалом та творчість Ю. Андруховича зокрема досліджували Т. Гундорова, Н. Зборовська, С. Павличко, М. Павлишин, М. Рябчук, Ю. Шерех та ін. У їхніх працях можна детально ознайомитись 3 науковим та художнім мисленням в умовах постколоніальної дійсності, бо перш ніж перейти до аналізу роману, потрібно зрозуміти час, в якому творився текст.

«Перверзія» - роман-пастиш, який включає в себе передслово, післяслово видавця, 31 фрагмент та паратекст, що утворюють суперструктуру дискурсу. Це зразок некласичного наративу, відмінного від традиційного художньої оповіді. Ю. Лєвін виділяє такі ознаки вище зазначеного виду оповіді: порушення правил правдоподібності; використання прийому «текст у 
тексті»; втручання авторського «я»; безпосереднє входження «реальності» у світ оповіді; використання поетичних структур у наративі тощо [4]. Це завжди дослідження і гра на рівні будови тексту, коли «відкриваються» прийоми його творення. У цій ситуації читач відіграє роль співавтора та переймає певні авторські функції. Таким чином, некласична оповідь позбавлена однозначності і самодостатнього характеру звичайної, лінійної оповіді, результатом якої $є$ непевність читача в статусі, способі існування зображеного художнього світу. Особливо цікавим у цій ситуації є статус наратора як ядра розповідного тексту. При аналізі слід звертати увагу на неоднозначності, білі плями в тексті, створення ефекту балансування читацької реакції, сумнівів як основних симптомів присутності ненадійного розповідача.

Оскільки маємо справу 3 нетрадиційним наративом та особливими оповідними стратегіями, можемо говорити про трансформацію карнавалу та його бачення Ю. Андруховичем. Невід'ємним атрибутом карнавалу є маска, яка в першу чергу є засобом набуття нового образу і нової сутності. Наталя Лобас у монографії «Карнавальна поетика міжвоєнної експериментальної прози» зазначає: «Маска - це перш за все - зміна / заміна обличчя (добровільна, чи примусова, бажана, чи небажана), новий тип поведінки, відмінний від попереднього, приховування однієї сутності з одночасною маніфестацією іншої. Маска - це завжди більше, ніж одна риса, це набір певних характеристик, що створює тип, схему, стереотип, усталений спосіб переживання світу. Важливим моментом кожної маски $\epsilon$ можливість їі впізнавання читачем. Маска повинна викликати певні асоціації змушує очікувати певної лінії поведінки, або ж, навпаки, затирає і не дозволяє проявитися очікуваним рисам та вчинкам. Кожна маска, у якому б контексті вона не існувала, несе на собі печать штучності, неприродності, не-істинності, а часто і штукатурства.» [6, с.111-112]. Юрій Андрухович у різний спосіб використовує карнавальну маску. В його арсеналі виокремлюємо маску автора, маску наратора, маску персонажа.

Маска автора. Однією з особливостей нетрадиційного дискурсу, до якого належить роман «Перверзія» $\epsilon$ постійна присутність автора. Наприклад, у своєму заповіті Стах Перфецький адресує «зібрання творів Р. - М. Рільке у 6-ти томах, подарункове видання (3 передмовою Беди Алеманна, німецькою мовою) - Юрієві Андруховичу, Івано-Франківськ» [1, c. 457], а видавець підписується нехитрими літерами Ю. А. «При фрагментарності та хаотичності, властивій постмодерному тексту, авторська маска - єдина єднальна ланка, за допомогою якої автор організовує реакцію імпліцитного читача»- зазначає I. Ільїн [цит. за 8, c. 193]. Він репрезентує читачеві власну інтерпретацію, часто іронічну. Автор «явно забавляється своєю авторською маскою і ставить під питання самі поняття вимислу, авторства, текстуальності і відповідальності читача». О. Осовський розглядає авторську маску як «спосіб приховування власного обличчя з метою створення у читача іншого (відмінного від реального) образу автора» [7, с. 138]. Часто це поняття розуміється як основоположний прийом містифікації, який полягає у переадресуванні тексту вигаданим авторам. Найбільш вживаною авторською маскою у такому випадку є маска видавця.

Ю. А. знайомить читача 3 подорожжю Стаха на Захід та версіями його діяльності, переліком імен героя та умовами створення цієї книжки. Видавець виділяє кілька компонентів матеріалів, на яких він самостійно і у своїй послідовності будував текст (програмки, інтерв'ю, документи, депеші, відеокасета, диктофон і т. п.), тканина якого зіткана з різнорідних мовних елементів, посилених паралінгвістичними факторами (інтонація, ритм, пауза, еліпсис), що допомагає відтворювати образ живої усної розповіді. Звертає увагу на фрагменти різними мовами, які занотував умовний наратор, «який знає все про всіх, який водночас $є$ всюди і немає ніде, крім літератури. Хто $\epsilon$ автором цих шматків?» [1, с. 183]. Видавець говорить про дві версії, звертається до читача, який має правдо на власні версії, або на «кілька власних версій». Бачимо, що гра - основний непохитний закон цього тексту. Отже, ще до початку основних подій сюжету у передмові оголюється структура організації тексту i, таким чином, з першого рядка починається конструювання авантюрної розповіді із прямим залученням читача.

Ю. Андрухович своїми текстами заперечує примітивне тлумачення бартівської тези про «смерть автора», яку здебільшого пов'язують саме з постмодерністською літературою. Автор постійно наголошує на своїй присутності, порушуючи таким чином, різні норми текстотворення, що мають, однак, художню функцію. Він постає у ролі режисера-інтелектуала, що іронізує над наївним читачем, який в усьому довіряє наратору-(сталкеру). Письменник 
неодноразово натякає читачеві на свою схильність до різноманітних «перверзій». Без сумніву, біографічний автор є джерелом власного художнього твору, але водночас свідомості нараторів та персонажів у жодному разі не можна ототожнювати 3 авторською. Перетини голосів i свідомостей персонажів, діалог із текстами культури, переплетення різних дискурсів стають передумовою виникнення гри тексту, розрахованої на провокування відповідних реакцій читача та його залученості до викриття ненадійного наратора.

Маска наратора. Особливістю наративного дискурсу роману «Перверзія» є реалізація в творі феномену ненадійного розповідача. У передслові Ю. А. розповідає про загадкове зникнення Станіслава Перфецького, реакцію італійського та українського суспільства та дві паралельні версії - зникнення та самогубства, «з якої так і не розвинулася третя - спільна лінія: самогубство, вимушене ззовні» [1, с. 171]. Читач до кінця тексту балансує між цими точками зору, аж поки не відкривається основна інтрига - Стах Перфецький «є справжнім автором усіх (не деяких!) фрагментів цієї книжки. Він живий i, я скажу більше, він повертається» [1, с. 476]. У цей момент, читачеві хочеться знову перечитати текст 3 урахуванням нового знання та розуміння. А це ще однин із симптомів присутності ненадійного розповідача - зміна враження від твору.

Ненадійність наратора також полягає у його розщепленні на кількох розповідачів, що $\epsilon$ нічим іншим, як відповідними масками, за допомогою яких він передає «різні» погляди на те саме явище. На одній фабулі твориться кілька сюжетів. Наприклад, у 25 фрагменті Стах розповідає про містичну імпрезу в давно забутому домі Фарфарелло, де все і всі змінюються і набувають демонічних обрисів. А у 26 фрагменті Ада сповіщає, що Стах під впливом алкоголю весь цей час спав і жінка ледве привела його до тями.

Зауважмо, що Ада та Різенбокк часто називають Перфецького Респондентом. Одне 3 визначень цього поняття таке: респондент - це людина, яка виступає в ролі джерела первинної інформації про явища і процеси, котрі досліджуються. Таким чином, це ще один натяк на Перфецького як автора всього сказаного у тексті.

Ненадійність наратора виражається на різних рівнях, насамперед, в мові та поведінці. Тому важливо визначити, що змушує дистанціюватись від наратора, сприймати все сказане 3 обережністю та відстороненістю. Звернімось до тексту. Наприклад, у першому фрагменті роману (після передмови) з'являється Стах, який паралельно розповідає дві історії: першу про Аду Цитрину та Януса-Марію Різенбокка, які везуть його до Венеції, а другу про «позавчорашні події», які сталися 3 березня після закінчення карнавалу у Мюнхені. Перфецький говорить: «Я сижу в їхньому «альфа ромео», припустімо, що це «альфа ромео» [1, с. 184]. Стас заплутується в інформаціях і до Венеції їх везе то «порше, чи що там у нього», то «феррарі, чи щось там таке», то «універсальний автомобіль четвертого покоління серії «Мантікора»». $Є$ один момент, коли Перфецький відходить від двох історій і розповідає про провали в пам'яті, про ідею 3 диктофоном [1, с. 188]. Це суттєвий сигнал для читача, що спонукає з обережністю сприймати сказане. Також з зі слів упорядника тексту Ю.А. дізнаємося про вади зору Станіслава, а саме, про короткозорість та про невід'ємний атрибут - окуляри, без яких майже нічого не бачив. Цей факт пояснює багато містифікаційних моментів, наприклад, появу на семінарі Альборака Джабраїлі $з$ конем, який, ставши перед Адою і Стахом, як вкопаний, виявляється ровером, «але теж доброї марки». У мавпі, яка грала на арфі, Стах пізнає старшу на 16 років жінку, яка колись давно по закінчені репетиції запросила його до «таємного саду, де він зазнав урагану ставання мужчиною». Перетворення, зміни зовнішнього вигляду та містифікації становлять основу карнавального дійства, цього «світу навпаки», все стає амбівалентним [3, с. 141-143]. Ілюстрацією цього відомого висновку М. Бахтіна може бути танцювальний номер з алегоричними фігурами, кожна 3 яких ззаду - чеснота, а спереду — один із найтяжчих гріхів.

Левова частина маскувань, переодягань та містифікацій все ж стосується фікційних персонажів.

Маска персонажа. Основу перевтілення становить ім'я, змінюючи яке, герой таки змінює схему поведінки. Проте чисельні маски не перетворюють Перфецького в іншого персонажа, натомість виражають певні смисли. Маска повністю втрачає ефект самостійної дійової особи і перетворюється на стереотип, який можна означити як «маска-без-обличчя». Герой не приховує свою сутність (оскільки знаходиться в пошуках власної ідентичності) і навіть не набуває нового образу. Це пік авторського іронічного задуму. Постійні перевтілення 
Стаха - це частина його амплуа. Перфецький - авантюристичний проект, який складається 3 калейдоскопу рухомих жанрових схем-масок. Кожне ім'я репрезентує інше обличчя поета, яке можна розпізнавати з огляду на внутрішню форму слова.

Отож, у передмові видавець заявляє, що детально вистежив «вперте, невпинне і непоминальне просування на Захід» Перфецького. У Кракові перед читачем з'являється Йона Риб, який почувався у місті «як риба у воді». Після успішних виступів та доповідей, Перфецький, він же Бімбер Бібамус, влаштував перфоманс у жидівських кварталах під назвою «Татарин у місті. Сцени з історії Кракова». Акція включала в себе розбиття чотирьох вітрин, дві стихійні бійки, ріки 3 алкоголю, а також «нічне читання найконтроверсійніших уривків із Шевченкової поеми «Гайдамаки» під пам'ятником Міцкевичу» [1, с. 177]. Потрапивши до поліції Перфецький, виправдовуючи свої екзотичні дії, знову міняє маску запевняючи, що «в нього було вселився дух легендарного татарського вершника, який за часів пізнього середньовіччя пострілом із лука на півноті обірвав життя пильного сурмаря з Мар'яцької вежі» [1, с. 177]. Це не переконало поліцію і діло відправляли до суду, проте чергове перетворення в Карпа Любанського допомогло «...вислизнути 3-за грат і, відчайдушно працюючи плавниками, розчинитися в непролазних безвістях». Наступна іпостась знову пов'язана з образом риби: «У другій половині жовтня Стах Перфецький, оновлений і прояснений, виринає (він же Сом Рахманський) 3 дунайських вод на береги Братислави...» [1, с. 178]. Далі видавець подає дві версії щодо діяльності Перфецького в період віденських вакацій. Згідно 3 першою він зустрічався невідомо $з$ ким і навіщо у якійсь конспіративній квартирі (маска таємного агента), а друга версія, «котра виглядає імовірнішою», говорить, що персонаж влаштувався танцюристом у стриптиз клуб під прізвиськом П'єр Долинський та «витинав складні еротичні фігури для задоволення старших пань, постійних відвідувачок». [1, с. 179].

Маски змінюють одна одну відповідно до набуття нової подоби. Наступним містом у подорожі на Захід була Прага, куди Перфецький дістався перевдягнутим жінкою і 3 підробленим паспортом. Основною локацією була смердюча пиварня в Жижкові, де герой в образі Йогана Когана дивував публіку своїм почуттям гумору, простодушністю, а також навчав чеських пияків українських пісень і тосту «Будьмо!». Далі був Берлін, куди герой, Камаль Манхмаль, дістався на саме Різдво. Потрапивши у ресторацію «Terzo mondo», в око Стаху впала молода грекиня Зоя. Яскраві емоції та піднесення внутрішнього стану спровокували появу нового образу - Перчила - який «прикипів (до дівчини) чимось дуже схожим до кохання». Бачимо, що новий вигляд провокує певний демонстративно штучний тип поведінки. Останнім пунктом перед пригодами у Венеції був Мюнхен, де Стах перебуває під йменням Штрудль і різко зникає з поля зору загадкового видавця. Цікаво, що назва одноіменного різновиду тістечок походить від німецького слова Strudel, що буквально перекладається як «водоверть, вихор». І якщо взяти до уваги, що образ риби є наскрізним у творі, а місце основної дії - місто на воді, то це слугуватиме знаковою підказкою для читача.

Карнавальна зміна одягу в романі «Перверзія» сприймається як зміна життєвого становища, як приховування або набування іншої сутності. Показовими в цьому аспекті $є$ дивні метаморфози на згаданій вечері у домі Фарфарелло: слуга-китаєць перетворюється на гостесу в місячно-блідій сукні, згодом - на секретаря Даппертутто; Мавропуле - на чорного віслюка в єпископській тіарі й сутані, а відтак - на слугу-китайця, після чого стає зозулястим півнем у таких же точнісінько окулярах, як Перфецький, пізніше, почувши характерний Мавропулів клич, Стах бачить голову бика, що «вдоволено сопіла і підморгувала до нього», а в кінці вечері Мавропуле перетворюється на духа Бахафу, який закликав усіх у сади володаря. Прикладів подібних переодягань і перетворень безліч: Ада, яка постійно одягалася в чорне і вишневе, на вечері вперше з'являється у невластивій для себе темно-зеленій барві та 3 перстнем-жабою; Лайза Шейла, в якої широкий чоловічий (!) капелюх майже повністю прикривав обличчя, перетворюється на змієтілу крилату ламію, сукубу на ймення Ліліт. Всі учасники та гості семінару зазнали візуальних трансформацій, перетворившись «переважно в лемурів та єхиден та серен та восьмиоких драконів та мантикор з ляцертинами...» [1, с.430].

Такі, здавалось би, незрозумілі речі та невідповідності, трапляючись на кожному кроці в Андруховичевих персонажів, підводять до висновку, що роман - це своєрідна фантасмагорія в дослівному перекладі - розповідь про примару. Хіба не примарою є головний герой, Венеція, яку неоднорозово названо містом-привидом? У передслові наратор проговорюється, 
висловлюючи припущення, що падіння загадкового персонажа з готельного вікна також може бути якоюсь мистецькою акцією. Маска Станіслава під назвою Йона Риб має у творі найбільше конотацій. Існують певні символічній паралелі між ритуальним вбивством рибини i самопочуттям Перфецького, про що вже згадувалося вище, і постійна присутність образу риби в романі, зокрема: розвага Януса Марії Різенбокка полягала в спостеріганні за тим, як у великому акваріумі риби-хижаки знищували малечу, тоді могутній Риб поїдав хижаків, а згодом Риба вбивали ножем на кухні; на урочистій вечері під час пошуків Ади Перфецький опиняється в акваріумі посеред рибин, а коли акваріум падає і розбивається, Стах покидає самого себе; кінокефал, який полює за Стахом, із задоволенням смакує рибою; навіть Венеція 3 висоти пташиного польоту «має форму риби, перетятої оберненою літерою $\mathrm{S}$ (Каналь Гранде)». Риб'яча сутність «перверзійного» персонажа дуже добре пояснює, чому він любив дивитися на воду і хотів би в ній навіть жити: «Додому. До води. Риба хоче плавати. Мене чекає океан» [c. 470]. Відповідно, самогубство Стаха Перфецького можна розглядати як повернення до життя, до своєї автентичності, як осягнення онтологічної свободи.

Висновки. Отже, роман «Перверзія» - подвійна маска подвійної гри (i автор, i нараторперсонаж бавляться). Існує ряд порушень в текстотворенні: присутність автора, взаємозв'язок дієгезису та реального позатекстового світу, калейдоскоп текстів у тексті, різноманітні імена персонажа, їхня поетика та семантика. Відбувається деформація художнього світу: порушення дейктичного паритету між автором і читачем. Перфецький існує в кількох іпостасях: як персонаж і як розповідач. Ненадійна нарація показує суперечливу, містифіковану картину уявного можливого світу. Самі вагання стають предметом зображення, адже вагаються всі учасники комунікативного акту: i читач, i наратор, i персонаж. Твір вимагає для свого розуміння певної перебудови та адаптації художнього, ідеологічного, традиційного сприйняття. 3 кожним прочитанням відкриваються нові елементи смислу.

\section{ЛIТЕРАТУРА}

1. Андрухович Ю. Два романи. Івано-Франківськ : Лілея-НВ, 2014, 480 с.

2. Бахтин M. Творчество Франсуа Рабле и народная культура средневековья и Ренессанса. URL: http://www.bim-bad.ru/docs/bakhtin_rablai.pdf

3. Бахтин М. Проблемы поэтики Достоевского. М.: Советская Россия, 1979. 318 с.

4. Левин Ю. И. Избранные труды. Поэтика. Семиотика. М.: Языки русской культуры, 1998. 822 с.

5. Литературная энциклопедия терминов и понятий / гл. ред. и сост. А. Н. Николюкин; М. : Интелвак, 2001. 1600 стб.

6. Лобас Н. Карнавальна поетика міжвоєнної експериментальної прози (Майк Йогансен versus Вітольд Гомбровіч): Монографія. Тернопіль: Видавничий центр ТОВ «Компанія КРОК»; «Підручники і посібники», 2009, 264 с.

7. Семащук Н. Маска у художньому тексті: спроба типології явища // Терміносистеми сучасного літературознавства: досвід розробки і проблеми: Науковий семінар / За редакцією Романа Гром’яка. Тернопіль: ТНПУ, 2006, С. 135-144.

8. Современное зарубежное литературоведение: страны Западной Европы и США: Концепции. Школы. Термины. М.: Интрада, 1999, 320 с. 